\title{
A Model of Community-Based Development in Digital Nomad Tourism in Intaran Village Bali
}

\author{
I Gusti Ketut Gede*, Kadek Eni Marhaeni, I Wayan \\ Putrana \\ Jurusan Administrasi Niaga \\ Politeknik Negeri Bali \\ Badung, Indonesia \\ *igkgede@pnb.ac.id, kadekenimarhaeni@gmail.com, \\ wayanputrana@pnb.ac.id
}

\author{
I Gusti Agung Mirah Sanjiwani \\ Manajemen Perhotelan \\ Institut Pariwisata dan Bisnis Internasional \\ Denpasar, Indonesia \\ mirahsanjiwani1701@gmail.com
}

\begin{abstract}
Tourism in Bali cannot be separated from the use of information technology such as the internet in this digital era. The use of this technology will make it easier for the visitor, both on tours and works, or known as digital nomad tourism. Ubud and Canggu are two succeeded areas in developing digital nomad tourism. Other tourism areas such as Sanur which also have coworking spaces, it is also potential to develop digital nomad tourism. Restaurants in the Sanur tourism area also have the same opportunity to develop their business into a co-working space. This research aims to develop a community-based digital model of nomad tourism in the local community of Intaran Sanur Denpasar in improving the welfare of themselves. The number of places suitable for this new tourism development in Sanur provides more space for business. The research was conducted with a quantitative approach supported by interviews and observations. The result shows three factors able to support the development of community-based digital nomad tourism, namely the entrepreneurial spirit factor in the digital world, the digital nomad tourism business factor as a new business alternative, and the ease of doing business. This research shows that communitybased tourism businesses in the Intaran village can be developed into a co-working space to support the development of digital nomad tourism.
\end{abstract}

Keywords-digital nomad tourism, internet, Intaran local community

\section{INTRODUCTION}

Tourism development in global becomes the fastest growth industry in the world as reported by the UNWTO, based on the international tourist arrivals that increased 7\% in 2017 than the previous year [1]. This sector also impact the world economic in increasing national income for some countries and creating job opportunity. UNWTO also mentioned in 2018 that tourism sector generate USD 1,6 billion [2]. The development of this sector also happened in Indonesia significantly by the increasing number of international tourist arrival reach more than 14 million or $21,44 \%$ than the previous year in 2016 and in 2018, it reached 15,81 million visitors. National income for tourism sector is around USD 13,5 billion in 2016 and becoming the second national income after palm oil (USD 15,9 billion). Tourism sector reached USD 16,8 billion income in 2017 [3]. Growth of tourist arrivals in the past five years from 2013 until 2018 is around $13,3 \%$, but the number of arrivals decreased $3,37 \%$ in 2019 . It will be more decrease in 2020 caused by the pandemic of Corona Virus Disease (Covid-19). Tourism sector is sensitive to issues of cleanliness, environment and health; therefore, it is necessary to have a strategy to develop other tourism product. Information and communication technology becomes the other development that also grow rapidly with tourism. It shows that the internet user around the world reach 4,54 billion users or more than $60 \%$ population in the world. According to Digital Report 2020, there are two key points such as social media and internet user behaviour. Both of this point will help people to determine various business opportunity. Internet was used in 6 hours 46 minutes in 2018 and decreased 3 minutes become 6 hours 43 minutes in 2019. It is used increasingly in mobile device by the total internet usage that reached $50,1 \%$ or 3 hours 35 minutes [4]. The availability of internet in every spot of tourism industry will help tourist to get more information about the destination.

The tourism developed in Bali is also become opportunity to create another business in order to increase the national income, instead of developing cultural tourism. Bali is known in the whole world, also becomes the best tourist destination from The Best 25 Destination in the world based on Travellers Choices [5]. The development was seen by increasing of some parts, such as hotel, villa, uniqueness of tourist attraction, beauty of nature, and beaches as the magnet of tourist to spend their holiday.

Bali has become a centre of Digital Nomad in Indonesia, instead of developing cultural tourism since long time ago. Digital nomad is a tourist who works and live from one to another destination which they use technology and do their activity in a café or co-working space, also using laptop that connected to the internet. This generation is a business owner and freelancer which take advantage of choosing any location 
to do more sightseeing and exploration. This type of tourism will be able to develop some café, restaurant or build a new establishment of co-working space to reach this nomads visitor.

Sanur as a part of Denpasar city (capital city of Bali) is a potential area that might be develop Digital Nomad tourism, since the development of tourism happened in this place for such a long time ago. Sanur consisted of 3 villages namely Intaran Village (with 20 community group), Sanur Village (with 8 community group) and Penyaringan Village (with 1 community group). All of those villages encourage themselves to develop their potential, including as a souvenir seller, food and beverage, accommodation, and cafe in order to do their job and gain income. Therefore, the problem in this research is (a) What are the characteristics of the Digital Nomads Tourism that is developing in Bali? (b) What is the Digital Nomads Tourism model that can be developed based on the community in Intaran Village to improve community welfare?

\section{LITERATURE REVIEW}

\section{A. Business Opportunity}

Recognition of the capabilities of business opportunity and making it happen is at the heart of entrepreneurship. There are three types of business opportunities [6], namely opportunity recognition, opportunity discovery, and opportunity creation. Getting know the opportunity is concerned with combination of existing demand with the supply side through existing or new firms. There is no new creation of the demand or supply side. Meanwhile, opportunity discovery arises from the absence of both the demand and supply sides, meaning that there is an opportunity to create new demand or new supply. Then the highest degree is the creation of opportunities that come from inventions / new inventions of goods, services or technology that can create new offers and new demands. The first activity (opportunity recognition) is most suitable to be carried out by students, the second activity (opportunity discovery) requires higher experience and expertise, and the last is that opportunity creation can only be done by inventors or inventors as a result of a research laboratory. The introduction of this opportunity is closely related to the entrepreneurial learning process [7].

Opportunity is taking benefit from all of the productive activity possibilities [8]. Business opportunity is a whole activity of taking benefit from new individual and organization knowledge development, changes of behaviour of economic factors such as consumer suppliers, etc., and changes in various kinds of macro environment including technology [9].

\section{B. Entrepreneurship}

It is necessary to have the following characteristics of an entrepreneur: optimism, courage to take risks, passion, integrity, superior culture, forward thinking, conscious time and means, dreams, planning, main strategies, financing, location, instead of leadership factors as an individual. The characteristics of entrepreneurship are as follows: brave and creative, high spirit and firm, good analytical power, become a leader and not a consumptive, decision maker and implement them, have great devotion to their business. An entrepreneur have to implement their entrepreneurial mind towards the customer and potential customer, instead of themselves. A professional entrepreneur will be able to do this: know and believe their product, able to receive constructive feedback without debating with customer or potential customer, good communication skill to their staff and customer, wellmannered, honest, decision maker, take responsibility if the product or service caused losses on customer. Here are some of the goals of an entrepreneur:

- Open new jobs for others and help them become selfemployed.

- Create a new business network that can absorb a lot of workforce around it.

- Improving the well-being of his life and also the community around the efforts carried out by opening jobs.

- Communicate and develop entrepreneurial spirit to others.

- Help young entrepreneurs to create and innovate.

Entrepreneurial spirit is the soul of independence to find a source of income by opening a business or channelling the creativity of a person to then be used as a land to earn income such as mental attitude, leadership, governance, and skills [10].

\section{Online Business}

The development of the internet provides business opportunities without the limitations of space and time. The business phenomenon of this century is the existence of online business or also called electronic business or e-business. Grefen [11] defines e-business as conducting core business activities in a way that is enabled by the integrated use of information technology for information processing and communication. Then online business is the main activity of business by using information technology integrated to process and communicate information. Turban and Rainer [12] added that online business includes a variety of computer-based activities with internet networks that include the sale and purchase of goods and/or services, customer service, partnership cooperation, and electronic transactions. Structurally, e-business includes various activities of business functions, including e-marketing, e-purchasing, e-learning, egovernment, e-health and others.

\section{Digital Nomad Tourism}

A digital nomad is an expert who live and works from one place to another as their wish, and it is currently a millennial lifestyle practiced widely by writers, consultants, programmers, website developers, photographers, translators, or internet marketing. They are able to work freely anywhere as long as there is an internet connection. Digital nomad workers work in public places, such as restaurants, malls, cafes, or coffee shops which provide high speed internet access. In fact, currently 
there is also a new trend, namely coworking space. In Indonesia, it is predicted that there will be more than hundreds of coworking spaces in the next year due to the trend of digital nomad and start-ups.

It seems that internet is difficult to be removed from daily activities and work. The internet able to create many job opportunities, many freelancers such as writers, data entry, designers, programmers and many more. Besides, remote work using the internet can create a change in the mindset of today's youth. They do not feel that a permanent job is necessary, but freelancing can create income to support their daily life. This kind of phenomenon becomes more popular when there are tourists who become freelancers, or it can be categorized as digital nomads.

Ikhsanti [13] mentioned that digital nomad is a term for people who do not live in a certain place for a long time and work remotely using the internet. There are five benefits of being a digital nomad: (i) independent location, (ii) simple to start a working atmosphere, (iii) unlimited creativity, (iv) flexible working time and support for workspace [14]. This development creates a new tourism model known as Digital Nomad Tourism which is a combination of two digital nomadic activities and tourism. Digital nomads are individuals who do not depend on a fixed work area and special space to work, but the only thing required is a high-quality internet connection to be able to help their work [15-19].

Previous research conducted concluded that Bali is already famous as a place for digital nomads, therefore this type of tourism can be developed and promoted more seriously [20]. Two popular destinations for digital nomads are Ubud and Canggu and possible to be opened or developed in other tourist destinations in Bali. The pull factors that must be considered in the development of this tourism are a) affordable expenses, b) the availability of suitable facilities, c) friendly communities, d) various weekly events (Entertainment). Digital nomad chooses Bali because of the weather and beauty of the island of Bali, openness and tolerance, electricity, water, internet, a group of friends of the same profession. There are many creative talents from various countries who gather in Bali. This thing increases the attractiveness of Bali as not only a tourist destination city but also a work vacation spot (Living and working in paradise: the rise of the 'digital nomad). This digital nomad is not taking the jobs of local residents; they have their own jobs and need a fresh atmosphere to support their work productivity. The number of digital nomads in Bali will attract more people with similar professions and have a positive impact on the investment in Bali.

\section{RESEARCH METHODS}

Research was done in Intaran Village which the community works mostly in hospitality industry. Covid19 pandemic causes some company closed and not operating as usual, but two restaurants that managed by the local community still opens and operating daily; Waroeng Madu Sedana and D'Mel, which is located in Intaran village. Both of these restaurants hire local community as an employee from their own community group and consists of 10-30 person. This research is quantitative research supported by qualitative approach with data collection methods through observations, interviews, questionnaires and documentation. The main informant is the manager of the business, employees and visitors involved in it with 100 people in total. Questionnaires were analysed using exploratory factor analysis with SPSS Program. All of the indicators will be extracted into some factors that represent the variance of three variables; digital nomad, online business and entrepreneurship.

\section{RESULTS AND DISCUSSION}

Digital nomad are tourists who visit Bali in addition to enjoying attractions and also complete their work without being bound by space and time and always moving (nomads). Online business opportunities are opportunities that are influenced by the rapid development of information and communication technology, both in terms of hardware and software. The famous coworking space in Bali such as Hubud (founder: Steve Munroe, Peter Wall dan John Alderson) in Ubud, Dojo Bali (founder: Michael Craig) Echo Beach in Canggu, Outpost Canggu (founder: David Abraham dan Bryan Stewart) in Canggu and Sanur Creative Hub (Alm. Arif "Ayip" Budiman) in Sanur. All of those places was managed by noncommunity of Sanur, Intaran village in particular, but mostly they were foreigners. The opportunity to establish new tourist attraction namely Digital Nomads Tourism is widely open, since there are amenities provided for the tourist. Facilities provided at those coworking space such as workplace with high-speed internet, comfortable atmosphere in indoor and outdoor, meeting room, coaching room, digital membership card, SuperPass by using phone to get the access (barcode scanning), mail address, storage locker, Skype Booth, and 24/7 access. They also provide various rate for the member (daily, monthly, three monthlies, and hourly). Advantages of living a digital nomad lifestyle such as independent location, easy to get the mood for working, unlimited creativity, flexible working hours, and coworking space support.

Some characteristics of digital nomad choose Bali as the destination, especially Ubud and Canggu including [20]:

- Provide coworking space and co-living (accommodation)

- Individual consideration, such as :

○ The weather, because Bali has good weather

- Easy access to tourist attractions including internet access

- A variety of tourist attractions, including nature, culture and hospitality

- Amenity can be one of the requirements for tourists that will make them stay longer in a particular tourist area including accommodation, food and beverages

- Involvement of tourism institutions that support tourist destinations so that they are worth visiting, 
including security aspects which can bring comfort to tourists

- Natural environment

- Travel bureau, advertising and marketing services

- Various special events that have never been found in their country of origin

- Corporate incentives

- Visit friends and relatives

- Gift (Souvenir)

- Cheap item prices.

- Cheaper and affordable cost of living (compared to in home country)

- A polite and friendly community (community)

The results show that there are three factors that can support the development of community-based digital nomad tourism, namely the entrepreneurial soul factor in the digital world, digital business nomad tourism factor as a new business alternative, and ease of business. This research shows that community-based tourism businesses in Intaran village can be developed into a coworking space to support the digital development of nomad tourism. The entrepreneurial spirit in the digital world has become one of the most important factors for digital nomad tourism managers in Intaran village in developing digital nomad tourism business. Mental attitude, leadership, skills, enthusiasm, creativity and courage to take risks are some of the characteristics that entrepreneurs should have. The soul of independence to find a source of income by opening a business or channelling the creativity of a person to then be used as a land to earn income.

The development of digital nomad tourism is influenced by three elements, such as digital nomad, online business, and entrepreneur in managing the business. A model can be drawn for a community-based development of digital nomad tourism are shown in Figure 1.

The opportunity in developing coworking space is becoming a new potential business in tourism sector. The coworking space has been evolving since 2013 and grow rapidly with very potential market segment, even though due to the Covid19 pandemic causes challenges to their operational. But by seeing the development of information and communication technology, this business will be more developed. This is due to the young generation that dominates the Indonesian population which is certainly not easy to control this as a potential market segment with the highest loading factor value with a percentage of variance for that factor is $21.169 \%$, but still dominated by the ecclesiastical and not community based. It will be more meaningful if the management is done by local community (who lives in the location of this business), because the economic turnover will occur in the village and themselves. Moreover, it is managed by a cooperative based on family and cooperation.

The questionnaire was valid and reliable based on the result that show the indicators is exceeding the criteria $(0,634>0,235$ and $0,872>0,6)$. The result of factor extraction can be seen in Table 1.

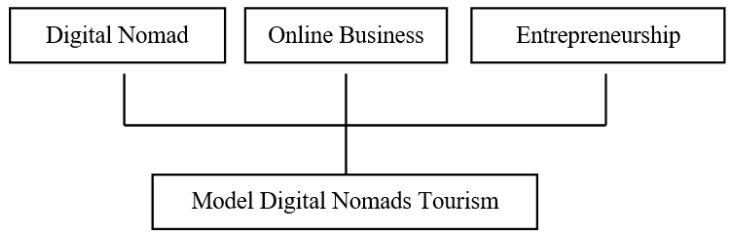

Fig. 1. A model of community-based development in digital nomad tourism

The existence of business opportunities that no longer need a permanent place of business (4) has the highest loading factor value, which is with a percentage variance percentage of $18.960 \%$. Many businesses have begun to think of a place of business that requires a considerable investment, in addition to the operating costs and maintenance required when setting up a place of business. On the other hand, it will provide the existing efforts to diversify its efforts into more promising efforts and future developments to grow rapidly. Coworking space should be able to accommodate the needs of workers such as comfortable space, office furniture, food and beverage facilities, and of course WIFI and other equipment. It is more important to have the professional management to develop the business in this very competitive industry.

TABLE I. FACTOR ROTATION

\begin{tabular}{|c|c|c|c|c|}
\hline No. & Indicators & \begin{tabular}{c|} 
Loading \\
Factor
\end{tabular} & $\begin{array}{c}\text { \% of } \\
\text { Variance }\end{array}$ & Factor Name \\
\hline 1. & $\begin{array}{l}\text { Attitude and } \\
\text { independence of business } \\
\text { manager (13) }\end{array}$ & 0,850 & \multirow[t]{6}{*}{23,687} & \multirow[t]{6}{*}{$\begin{array}{l}\text { Entrepreneurship } \\
\text { in digital era }\end{array}$} \\
\hline 2. & $\begin{array}{l}\text { Innovation of business } \\
\text { manager (11) }\end{array}$ & 0,701 & & \\
\hline 3. & $\begin{array}{l}\text { The availability of } \\
\text { information and } \\
\text { communication } \\
\text { technology facilities (12) }\end{array}$ & 0,673 & & \\
\hline 4. & $\begin{array}{l}\text { Work and travel needs } \\
\text { (10) }\end{array}$ & 0,623 & & \\
\hline 5. & $\begin{array}{l}\text { Digitalization in human } \\
\text { life (6) }\end{array}$ & 0,573 & & \\
\hline 6. & $\begin{array}{l}\text { Handphone as primary } \\
\text { needs (3) }\end{array}$ & 0,486 & & \\
\hline 7. & $\begin{array}{l}\text { Awareness of community } \\
\text { for online business } \\
\text { opportunity (5) }\end{array}$ & 0,783 & \multirow[t]{4}{*}{21,169} & \multirow[t]{4}{*}{$\begin{array}{l}\text { Alternative } \\
\text { business } \\
\text { opportunity }\end{array}$} \\
\hline 8. & $\begin{array}{l}\text { Digitalization in human } \\
\text { life (1) }\end{array}$ & 0,728 & & \\
\hline 9. & $\begin{array}{l}\text { Business development to } \\
\text { support digital nomad } \\
\text { tourism (8) }\end{array}$ & 0,709 & & \\
\hline 10. & $\begin{array}{l}\text { Internet support daily } \\
\text { activity of everybody (2) }\end{array}$ & 0,596 & & \\
\hline 11. & Business opportunity (4) & 0,789 & \multirow[t]{3}{*}{18,960} & \multirow{3}{*}{$\begin{array}{l}\text { Ease of doing } \\
\text { business }\end{array}$} \\
\hline 12. & $\begin{array}{l}\text { Dynamic employment } \\
\text { system (7) }\end{array}$ & 0,781 & & \\
\hline 13. & $\begin{array}{l}\text { Business development by } \\
\text { upgrading internet to } \\
\text { fulfill customer need (9) }\end{array}$ & 0,597 & & \\
\hline
\end{tabular}


Based on the result and observation in Waroeng Madu Sedana and D'Mel, the facilities provided in both of this community-based company are able to be developed as a place for digital nomad tourism. Both of this restaurant complete with indoor and outdoor tables with chairs, air conditioner, Wi$\mathrm{Fi}$, meeting room with several of style, and audio-visual equipment's (3 LCDs with giant screen). Waroeng Madu Sedana provide three rooms; two rooms fit for 30-person (Ushape) and one room (theatre style) fits for up to 200 people. D'Mel is able to accommodate maximum 40 person, but there is a balcony with 10-person capacity for holding a meeting.

Based on the characteristics of digital nomad tourism that already exists in Bali and also the benefits expected by digital nomad workers, then the development of this new type of tourism will certainly be able to be developed not only in Ubud or Canggu managed by expatriates only. This new type of tourism can also be developed based on community, because according to the results of research and observations in both of the restaurants in Intaran village for one year. Both of them also provided meeting space and dining area with free WIFI are able to be developed into a digital model of nomad tourism. Waroeng Madu Sedana is located at Jalan Batur Sari No. 25 Sanur Kauh South Denpasar Subdistrict Denpasar City, Bali which is managed as a business unit from the SIDI Multipurpose Cooperative Unit of the Autonomous Business Unit "Madu Sedana". The other one is namely D'Mel, which is located at Jalan Karang Sari No.16, Sanur, Denpasar South District Denpasar City, Bali as a business unit from SIDI Multipurpose Cooperative Unit Autonomous Business Unit "Sri Artha Sedana".

\section{CONCLUSION}

Digital nomad tourism that develops in Bali is complete with coworking, good weather, easy access, internet access, a variety of tourist attractions, beautiful natural attractions, culture and friendly local community, amenities, the involvement of tourism institutions that support tourist destinations, security of destination. Those aspects are able to lead the comfort, friendly natural environment, existence of travel agency services, and existence of special events that have never been encountered in their origin country.

A community-based digital nomad tourism model can be developed in Intaran village, Sanur. Three elements in this model are digital nomad, online business opportunities and a good entrepreneurial spirit for managers and supporters becomes the important things to develop this new tourism. The result shows that three factors; entrepreneurship in digital era, alternative business opportunity, and ease of doing business will help the community to develop this kind of tourism. Moreover, community-based management in business improve the welfare of the community and ensure the community still employed to get monthly income even in the new normal conditions of the Covid 19 pandemic.

\section{ACKNOWLEDGMENT}

This research was fully funded by the Indonesian Minister of Education and Culture through the Bali State Polytechnic DIPA Budget 2019 flagship research scheme.

\section{REFERENCES}

[1] UNWTO, Sustainable Development, 2010. [Online] Retrieved from: http://sdt.unwto.org/en/ content/ about-us-5.

[2] UNWTO, Tourism Highlights, 2018.[ Online] Retrieved from: https://www.e-unwto.

[3] Fakta.news, Sektor Pariwisata Indonesia sebagai Kekuatan Ekonom Utama Serta Penghasil Devisa Terbesar, 2017. [Online] Retrieved from: https://fakta.news/berita/sektor-pariwisata-indonesia.

[4] Anonimous, Digital, 2020. [Online] Retrieved from: https://wearesocial.com/digital-2020.

[5] Anonimous, Congratulations Bali Worlds 1 Best Destination Ttripadvisor 2017, 2017. [Online] Retrieved from: https://baligolive.com/articles/congratulations-bali-worlds-1-bestdestination-tripadvisor-2017.

[6] S.D. Sarasvathy, N. Dew., R. Velamuri, and S. Venkataraman, Three Views of Entrepreneurial Opportunity. In Acs, Z. and Audretsch, D. (eds), Handbook of entrepreneurship research Dordrecht: Kluwer the Netherlands, 2003, p.141-160.

[7] D. Dutta and M. Crossan, "The nature of entrepreneurial opportunities: understanding the process using the 4I organizational learning framework," Entrepreneurship: Theory and Practice, vol. 29, no. 4, pp. 425-449, 2005

[8] M. Gruber, I.C. MacMillan, and J.D. Thompson, "Escaping the prior knowledge corridor: What shapes the number and variety of market opportunities identified before market entry of technology start-ups?," Organization Science, vol. 24, no. 1, pp. 280-300, 2013.

[9] D.A. Grégoire, P.S. Barr, D.A. Shepherd, "Cognitive processes of opportunity recognition: The role of structural alignment," Organization Science, vol. 21, no. 2, pp. 413-431, 2010

[10] Anonimous, Jiwa Kewirausahaan, 2019. [Online] Retrieved from https://binus.ac.id/entrepreneur/2019/07/04/jiwa-kewirausahaan.

[11] P. Grefen, Beyond E-business: towards networked structures. Routledge, 2015.

[12] E. Turban and R.K. Rainer, "Introduction to Information Systems: Supporting and Transforming Business," John Wiley \& Sons, 2008.

[13] D. Ikhsanti, Siapa Digital Nomad Dan Bagaimana Caranya Menghasilkan Uang Jarak Jauh?, 2017. [Online] Retrieved from: https://www. aturduit.com /articles/penghasilan-dari-dunia-digital.

[14] R. Novriandi, Lima Keunt ungan Jadi Pekerja Nomad, 2017. [Online] Retrieved from: www.kincir.com/chillax/job-education/5-keuntunganjadi-pekerja-digital-nomad.

[15] T. Makimoto and D. Manners, Digital Nomads. Chichester: Wiley Publisher, 1997.

[16] F. Dal Fiore, L. Mokhtarian, I. Salomon, and M.E. Singer, "Nomads at last"? A set of perspectives on how mobile technology may affect travel," Journal of Transport Geography, vo. 41, pp. 97-106, 2014.

[17] T. Mohn, The Digital Nomad Life: Combining Work and Travel. The New York Times, 2017

[18] S. Koeswologito, "Bali and the rise of Digital Nomad: And Do You Make the Cut?," Thrive Global, 2018.

[19] S. Koeswologito, "Bali and the rise of Digital Nomad: Bali has become a hub for Digital Nomads, with a growing community of remoteworking professionals living here. Thrive Global, 2018.

[20] A.G. Wiranatha, M. Antara, A.C. Wiranatha, P.S. Piartrini, I.B.G. Pujaastawa, and I.G.A.O. Suryawardani, "Digital Nomads Tourism In Bali," Journal Communications on Stochastic Analysis (COSA), vol. 13, no. $8,2019$. 